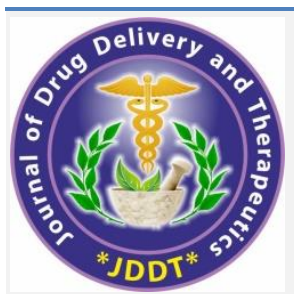

Open Access Full Text Article
Available online on 15.05.2021 at http://jddtonline.info

\section{Journal of Drug Delivery and Therapeutics}

Open Access to Pharmaceutical and Medical Research

(C) 2011-21, publisher and licensee JDDT, This is an Open Access article which permits unrestricted non-commercial use(CC By-NC), provided the original work is properly cited

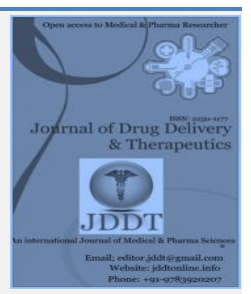

Research Article

\title{
In Silico Analysis of Laccifer Lacca as a Potential Therapeutic Agent for Cervical, Breast and Lung Cancers
}

\author{
Ashish Kumar, Neeraj Kumar and Balwan Singh* \\ HIMT College of Pharmacy, \#8, Institutional Area, Knowledge Park 1, Greater Noida, Uttar Pradesh, India -201310
}

\section{Article Info

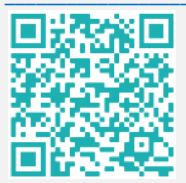 \\ Article History: \\ Received 23 March 2021 Reviewed 27 April 2021 Accepted 04 May 2021 Published 15 May 2021}

Cite this article as:

Kumar A, Kumar N, Singh B, In Silico Analysis of Laccifer Lacca as a Potential Therapeutic Agent for Cervical, Breast and Lung Cancers, Journal of Drug Delivery and Therapeutics. 2021; 11(3):79-85

DOI: http://dx.doi.org/10.22270/jddt.v11i3.4802

*Address for Correspondence:

Mr. Balwan Singh, Associate Professor HIMT College of Pharmacy, \#8, Institutional Area, Knowledge Park 1, Greater Noida, Uttar Pradesh, India -201310

\section{Abstract}

Laccifer lacca has generally been used as pigmenting, coloring agent and dying in chemical industry. Although, it has wide range of industrial applications, but inappropriately, due to lesser availability of data, it has been ignored. Keeping in mind, the wide application of Laccifer lacca, we tried to report the in-silico anti-cancer effects. The experimental techniques used to determine the structure was X-RAY diffraction. The reported resolution of this entry is $2.80 \AA \AA$. Percentile scores (ranging between $0-100$ ) for global authentication metrics of the record. In silico have a good pool to explore various parameters in molecular docking. We have performed in silico analysis of the active components of Laccifer lacca against the cervical, breast and lung cancer proteins and also found that lac extract enhances the production of anti-inflammatory markers and the increase is significant when compared to the standard vinblastine. It has been demonstrated by Lala and colleagues that a short lived molecule nitric oxide can result in the progression of human tumours. Therefore, the prominent antioxidant activity of phytochemical that can act as inhibitors of nitric oxide production can act as anticancer therapeutics. Both methanolic and aqueous extract shows significant anticancer effect on the hela, MCF-7 \& A549 cells suggesting them as potential anticancer therapeutics for future.

Keywords: Laccifer lacca, In-vitro \& In-silico analysis, Carcinogenesis, Anti-inflammatory, Molecular Docking.

\section{INTRODUCTION}

Lac resin is the major component in lac. The qualitative and quantitative analysis of the lac resin carried out in the past 200 years showed that lac resin is a mixture of polyester, which consists of polyhydric fatty acid and sesquiterpenoid acid. Its average molecular weight is about 1,000 and each molecule contains four or five hydroxyls containing one free carboxyl, one aldehyde group, two or three ester radicals, and one unsaturated bond. ${ }^{1}$ Lac resin is an acidic resin with a quite complicated chemical composition. Various acids can be obtained through basic hydrolysis of lac resin. Three chain aliphatic acids (aleuritic acid, kerrolic acid, and butolic acid) and eight cyclical terpenic acids (shellolic acid, jalaric acid, epishellolic acid, laksholic acid, epilaksholic acid, laccishellolic acid, epilaccishellolic acid and laccijalaric acid) had been separated.2,3 Lac is a multipurpose resin which has been applied in industries of military, electric appliance, printing ink, leather, plastic, metallurgy, machinery, woodworking, food, and medicine, etc. However, its shortcomings, such as brittleness, low softening point and bad water resistance, etc, limited its application. In order to expand its application field, various formulations were developed, some additives were employed in the modification of lac properties, and many lac products with special functions were produced. Luk was historically employed as an anti-hyperlipidemic and anti-obesity agent. A hyperlipidemia clinical trial in luk was performed twice a day for three months in a dosage of three grams. ${ }^{4,5,6} \mathrm{Lac}$ is an important drug of unani medicine and it has following medicinal properties like haemostatic, siccative, liver tonic, contraceptive, anti-inflammatory, anti-bilious, stomachic, aphrodisiac, detergent, deobstruent, anti-obesity, expectorant, kidney tonic, emmenagogues. And it is indicated to be used for following ailments, obesity, hyperlipidemia, renal, hepatic and spleen disorders, jaundice, ascitis, back ache, premature ejaculation, leprosy, cough, hemiplegia, asthma haemoptysis, epilepsy, chicken pox, ulcerations, palpitation etc. ${ }^{7}$ Laccaic acid, commonly known as lac dye, is the soluble part of stick lac from insect origin Coccus laccae (Laccifer lacca Kerr). The use of lac dye in the dyeing of silk and leather seems to have been known to the Chinese some 4000 years ago. In the north and the northeast of Thailand, lac dye is widely used as a natural red dyestuff for cotton and silk dyeing. Moreover, lac dye has also been reported as a natural food coloring. Laccaic acids are the combination of anthraquinone derivatives present in lac dye. The wax portion has long chain esters, alcohols and hydrocarbons. There are many reports on the antioxidant activity of the anthraquinone derivatives. ${ }^{8,9}$ Carminic acid is one of red dye which has the main constituent of an anthraquinone derivative same as the laccaic acid and it has been reported that carminic acid is as powerful antioxidant as ascorbic acid and even stronger than Trolox which indicates high antioxidant property. ${ }^{11}$ Recently lac dye has proven its biological activity as it has a similar structure with the anticancer drug Adriamycin (ADR) as both are anthraquinone 
derivatives. Antioxidant activity was investigated by DPPH assay, reducing power assay and the thiocyanate assay methods for laccaic acids and its aluminum lake. ${ }^{10}$ Laccaic acids are also having a potent anti-cancer activity where it inhibits direct DNA competitive inhibitor of DNA methyl transferase I. Moreover, in order to evaluate its biological activity in broader spectrum, we have undertaken other cancer cell lines such as hela, MCF-7 \& A549. In this paper, we report for the therapeutic potential of laccaic acid on three different cancer cell lines along with the isolation and characterization of the same with X-ray diffraction.

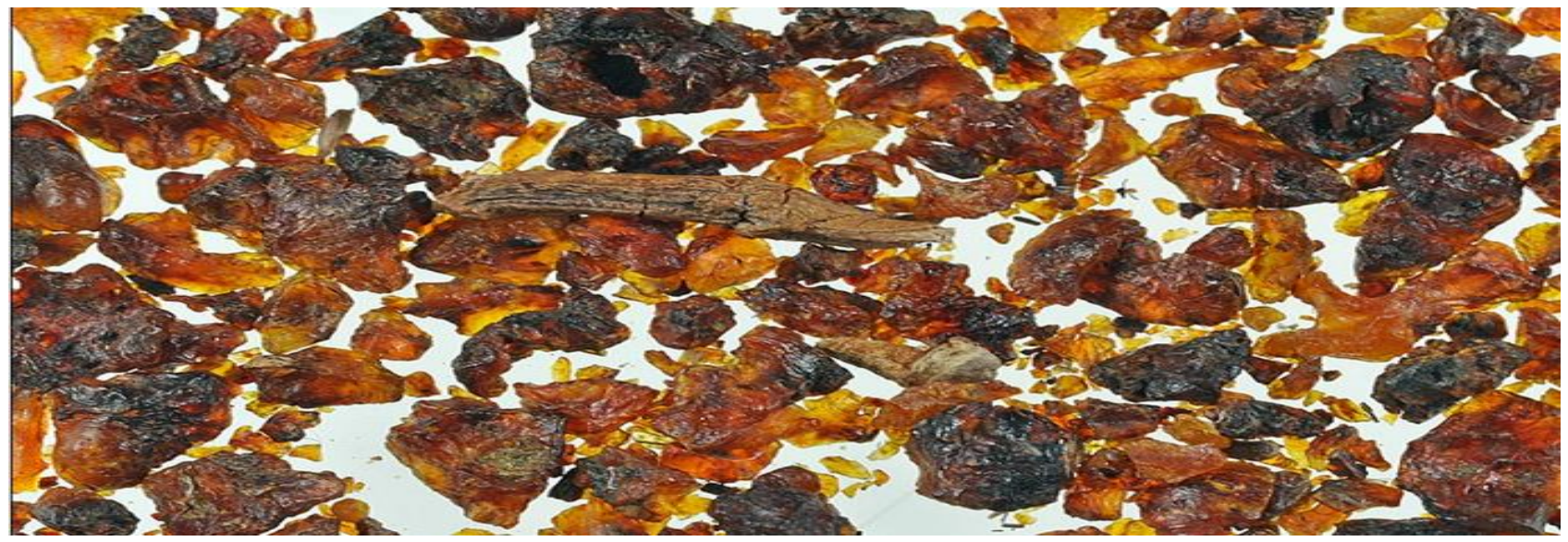

Figure 1: Laksha- Laccifer Lacca

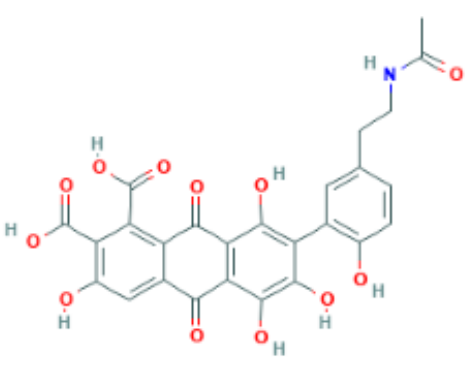

2D structure of Laccaic acid



3D structure of Laccaic acid

Figure 2: 2D, 3D structure of Laccaic acid

\section{MATERIALS AND METHODS}

Chemical and reagents Analytical grade reagents and chemicals were used for the study. Methanol, $0.22 \mu \mathrm{M}$ syringe filter, Mayer's reagent, Dragondroff's Reagent, Hager's Reagent, Ferric Chloride, Lead Acetate Solution, Trypsin, $\mathrm{NaCl}, \mathrm{KCl}, \mathrm{Na}_{2} \mathrm{HPO}_{4} 2 \mathrm{H} 2 \mathrm{O}$ and $\mathrm{KH}_{2} \mathrm{HPO} 4,10 \%$ fetal bovine serum.

Preparation of Methanolic extract (ME): Firstly, the Laccifer lacca was grinded to a coarse powder and kept in thimble chamber of soxhlet apparatus. After that, it was extracted in soxhlet extractor with Methanol solvent. Extraction solvent was heated on a heating mantle for about 6-8 hour at $50^{\circ} \mathrm{C}$. After cooling, the solvent was recovered by distillation method and the remaining liquid extract was cooled. Then, the filtrate was dried on water bath and stored for further use.

Preparation of Aqueous extract (AE): 250 gm of dried resins were taken and crushed in an iron mortar to obtain a coarse powder. The obtained coarse powder is then soaked in 2 litre of purified water for 24 hours. After 24 hours, the whole mass was transferred to the distillation plant. The mixture was then heated at 100 degrees celsius for 6 hours. After 6 hours, 1 litres of AE Was obtained. Then it was cooled and stored in a tightly sealed container to protect it from light and moisture. The prepared extracts will be filtered through $0.22 \mu \mathrm{M}$ syringe filter (Millex) and stored at $4^{\circ} \mathrm{C}$.

Cell culture: Cells were grown and maintained with $10 \%$ fetal bovine serum (FBS) and 1\% penicillin-streptomycin solution in the Modified Eagle Medium (DMEM) of Dulbecco, and held in a humidified $\mathrm{CO} 2$ incubator at $37^{\circ} \mathrm{C}$. When plates reached a $90 \%$ confluence with a 1:3 ratio, cells were subcultivated by scraping.

Plating of cells in 96-well plate: For plating, cells were taken out from $\mathrm{CO}_{2}$ incubator in to laminar flow hood and treated with $2 \mathrm{ml}$ of IX PBS. Then $1 \mathrm{ml}$ of trypsin was added and cells were put in $\mathrm{CO}_{2}$ incubator for $5 \mathrm{~min}$. the solution was transferred in falcon tube and $1 \mathrm{ml}$ of DMEM media was applied to it. Centrifugation of the tubes for 5 minutes at 1000 RPM. Supernatant was carefully discarded and $1 \mathrm{ml}$ of media pellet dissolved. Approximately 5000 cells per well were poured in 96-well plate and left in $\mathrm{CO}_{2}$ incubator for growth.

MTT assay for cytotoxicity: Cells were plated in a 96 well plate for the MTT assay at $5 \times 103$ cells/well. The MTT test was carried out for cell viability after 24 hour Extract treatment on the cells [3-(4, 5-dimetshiazol-2-yl)-2, 5diphenyl-tetrazolium bromide]. The medias for each well had MTT $(0.5 \mathrm{mg} / \mathrm{mL})$ added and a 3-hour incubation was made for each plate. After 3 hours of removal, $100 \mu \mathrm{l}$ Dimethylsulfoxide (DMSO) were applied to each well to overcome violet formazan crystals produced by MTT 
mitochondrial reduction of dehydrogenase. An ELISA plate reader read the absorption at $540 \mathrm{~nm}$ (ECIL).

Passaging cell line: To passage cells, T-flask containing confluent cell line was taken out from $\mathrm{CO}_{2}$ incubator in to laminar air flow hood. After observing the cell growth in inverted microscope, supernatant was discarded and washing was provided with $2 \mathrm{ml}$ of $10 \%$ PBS. Supernatant was discarded using a pipette. Cells were treated with $1 \mathrm{ml}$ of trypsin and incubated in $\mathrm{CO}_{2}$ incubator for $5 \mathrm{~min}$. Cells were transferred into new falcon tube and added with $1 \mathrm{ml}$ of DMEM media into it. Cells have been centrifuged for $5 \mathrm{~min}$ in 1000 RPM and supernatant is discarded, the pellet was dissolved properly into $1 \mathrm{ml}$ of DMEM media 2 new T-flask were taken into both flasks and both the flasks were put carefully in $\mathrm{CO}_{2}$ incubator. ${ }^{30}$

\section{RESULTS}

\section{Apoptosis measurement}

Remove the cells from the cultivation plate and suspend in PBS or serum-free medium for the attached cells. Centrifugal pellet cells at $600 \mathrm{xg}$ for five to six minutes. Remove the supernatant cells and replace the PBS cells. Make cell counts if needed. Remove the supernatant and dismantle it, pellet it again as before. Cell lysis, adding a sufficient volume of Lysis Buffer chilled e.g. 50 $\mu$ l, lysis of 1-5x 106 cells each. Vortex gently to suspend cells. Move into each well the buffer of $50 \mu \mathrm{l} 1 \mathrm{x}$ CasPASETM Assay and1X CasPASE ${ }^{\mathrm{TM}}$ Lysis Buffer . Into the suitable well, add $5 \mu$ l cell lysate as shown in the table. Add $5 \mu \mathrm{l} \rho \mathrm{NA}$ Solution Substrate. Mix well content and read at zero time point $(\mathrm{t}=0) .5 \mathrm{Mix}$ well content. Incorporate the plate to 20-37 degrees $\mathrm{C}$ at 6 . Measure the reaction at $405 \mathrm{~nm}$ each 30-60 minutes by reading the absorbance.

\section{Overall quality at a glance}

The following experimental techniques were used to determine the structure: X-RAY diffraction. The reported resolution of this entry is $2.80 \AA$ A . Percentile scores (ranging between 0-100) for global validation metrics of the entry are shown in the following graphic. The table shows the number of entries on which the scores are based.

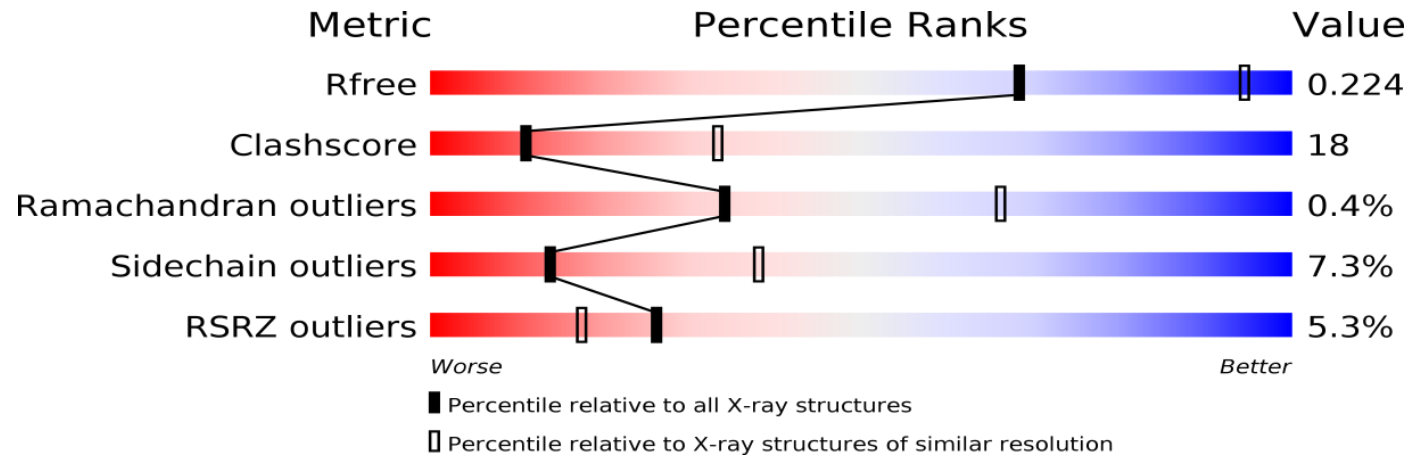

Figure 3: Percentile ranks at difference metric versus values

\section{Cell counting using haemocytometer}

During culturing with T-25, we have suspended $1 \mathrm{ml}$ of trypsinized cells in $2 \mathrm{ml}$ of full media (60-90\% confluence). A $1.5 \mathrm{ml}$ microfuge tube has been transmitted $200 \mu$ of cell suspension. $300 \mu \mathrm{l}$ PBS cells and 500 $\mu$ Trypan Blue solution 0.4 percent (dilution factor 5) in the microfuge tube have been treated. The solution was thoroughly mixed and given 15 minutes to stand. A cover slip has been applied to a haemocytometer chamber with a small amount of trypanoblue cell solution. This was done by touching carefully the edge of the pipette tip on the cover and allowing a capillary action to fill the chamber. Cells were counted on a $1 \mathrm{~mm}$ centre square and four edge squares (non-viable cells stain blue as viable cells remain opaque) We had to maintain a separate number of viable and unsustainable cells (if more than 25 percent of cells are nonviable, the culture is being maintained on appropriate amount of media). Each square of haemocytometer represents a total volume of $0.1 \mathrm{~mm} 3$ or $10-4 \mathrm{~cm} 3$. Since 1 $\mathrm{cm} 3$ is equal to $1 \mathrm{ml}$, subsequent cell concentration per $\mathrm{ml}$ was calculated by using (Peter D Pioli, 2019):

Cells $/ \mathrm{ml}=$ the average count per square $\mathrm{x}$ dilution factor $\mathrm{x}$ $10^{4}$ (count to 10 square).

Total cell number $=$ cells $/ \mathrm{ml} \mathrm{x}$ original volume of fluid from which sample was removed.

Table 1: Docking result of breast cancer

\begin{tabular}{|c|c|c|c|c|}
\hline File Name & Energy & Affinity & Re rank Score & Torsions \\
\hline $9883304 . \mathrm{mol} 2$ & -72.6162 & -19.9831 & -45.95 & 1 \\
\hline $9883304 . \mathrm{mol} 2$ & -72.4635 & -19.984 & -46.7525 & 1 \\
\hline $9883304 . \mathrm{mol} 2$ & -62.1362 & -24.1738 & -2.14455 & 1 \\
\hline $9883304 . \mathrm{mol} 2$ & -69.3368 & -22.0896 & -50.9315 & 1 \\
\hline $9883304 . \mathrm{mol} 2$ & -66.6058 & -19.9826 & -56.7165 & 1 \\
\hline
\end{tabular}


Table 2: Experimental Data Snapshot

\begin{tabular}{|l|l|}
\hline Method: & X-RAY DIFFRACTION \\
Resolution: & $3.21 \AA$ \\
R-Value Free: & 0.307 \\
R-Value Work: & 0.257 \\
R-Value Observed: & 0.260 \\
\hline
\end{tabular}

Finish (estimated): 11:52:21. Remaining: 00:00:02

Working path: C:/Users/Bashah/Desktop/data/barkha mam gbu/ibri assignment ashish/breast cancer/dock breast cancer result Current ligand (10/10 runs)

\begin{tabular}{|l|l|l|l|}
\hline Log & Poses (current ligand) [45] & Poses (all) [5] & Graph \\
\hline
\end{tabular}

\begin{tabular}{|llllll}
\hline Filename & Name & Energy & Affinity & RerankScore & Torsions \\
[00] 9883304.mol2 & {$[00] 9883304$} & -72.6162 & -19.9831 & -45.95 & 1 \\
{$[01] 9883304 . \mathrm{mol} 2$} & {$[01] 9883304$} & -72.4635 & -19.984 & -46.7525 & 1 \\
{$[02] 9883304 . \mathrm{mol} 2$} & {$[02] 9883304$} & -62.1362 & -24.1738 & -2.14455 & 1 \\
{$[03] 9883304 . \mathrm{mol} 2$} & {$[03] 9883304$} & -69.3368 & -22.0896 & -50.9315 & 1 \\
{$[04] 9883304 . \mathrm{mol} 2$} & {$[04] 9883304$} & -66.6058 & -19.9826 & -56.7165 & 1
\end{tabular}

Figure 4: Experimental data Snapshot of breast cancer

We found that Cell viability after treatment with the methanolic and aqueous extract of Laccifer lacca in the effect of L.L on MCF cell viability the methanolic and aqueous extract are same.

\section{Effect of L.L. on MCF-7 cell viability}



Figure 5: Cell viability after treatment with the methanolic and aqueous extract of Laccifer lacca. It is expressed in percentage in the ratio with the control cells.

Table 3: Docking result of cervical cancer

\begin{tabular}{|c|c|c|c|c|c|}
\hline File Name & Energy & Affinity & Re rank Score & Torsions & RMSD \\
\hline $9883304 . \mathrm{mol} 2$ & -89.626 & -20.6024 & -73.5286 & 1 & 36.404 \\
\hline $9883304 . \mathrm{mol} 2$ & -90.3559 & -19.7298 & -80.6672 & 1 & 35.7628 \\
\hline $9883304 . \mathrm{mol} 2$ & -86.3342 & -20.8158 & -70.6973 & 1 & 35.8864 \\
\hline $9883304 . \mathrm{mol} 2$ & -86.6803 & -20.5648 & -58.105 & 1 & 35.8337 \\
\hline $9883304 . \mathrm{mol} 2$ & -85.4526 & -20.6884 & -75.9282 & 1 & 36.2304 \\
\hline
\end{tabular}

Table 4: Experimental Data Snapshot

\begin{tabular}{|l|l|}
\hline Method: & X-RAY DIFFRACTION \\
Resolution: & $2.80 \AA$ \\
R-Value Free: & 0.294 \\
R-Value Work: & 0.243 \\
R-Value Observed: & 0.245 \\
\hline
\end{tabular}


Finish (estimated): 14:54:16. Remaining: 00:00:02

Working path: $\mathrm{C}: /$ sers/Bashah/Desktop/data/barkha mam gbu/ibri assignment ashish/cervical cancer/dock result

Current ligand (10/10 runs)

$100 \%$

\begin{tabular}{|l|l|l|l|}
\hline Log & Poses (current ligand) [36] & Poses (all) [5] & Graph \\
\hline
\end{tabular}

\begin{tabular}{|c|c|c|c|c|c|c|}
\hline Filename & Name - & Energy & Affinity & RerankScore & Torsions & RMSD \\
\hline [O0] $9883304 . \mathrm{mol} 2$ & [00] 9883304 & -89.626 & -20.6024 & -73.5286 & 1 & 36.404 \\
\hline [01] $9883304 . \mathrm{mol} 2$ & [01] 9883304 & -90.3559 & -19.7298 & -80.6672 & 1 & 35.7628 \\
\hline [02] $9883304 . \mathrm{mol} 2$ & [02] 9883304 & -86.3342 & -20.8158 & -70.6973 & 1 & 35.8864 \\
\hline [03] $9883304 \mathrm{~mol} 2$ & [03] 9883304 & -86.6803 & -20.5648 & -58.105 & 1 & 35.8337 \\
\hline [04] $9883304 . \mathrm{mol} 2$ & [04] 9883304 & -85.4526 & -20.6884 & -75.9282 & 1 & 36.2304 \\
\hline
\end{tabular}

Figure 6: Experimental data Snapshot of cervical cancer

We found that Cell viability after treatment with the methanolic and aqueous extract of Laccifer lacca in the effect of L.L on Hela cell viability the aqueous extract has more effect with comparison in methanolic extract.

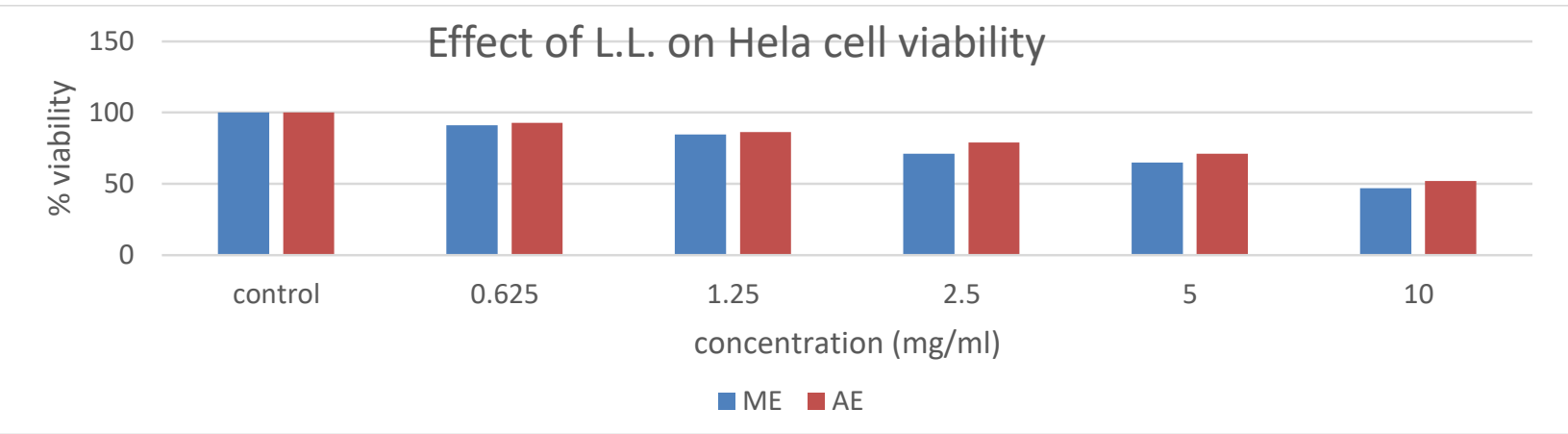

Figure 7: Cell viability after treatment with the methanolic and aqueous extract of Laccifer lacca. It is expressed in percentage in the ratio with the control cells.

Table 5: Docking result of lung cancer

\begin{tabular}{|c|c|c|c|c|c|}
\hline File Name & Energy & Affinity & Re rank Score & Torsions & RMSD \\
\hline 9883304.mol2 & -101.568 & -23.0736 & -6.8071 & 1 & 131.028 \\
\hline $9883304 . \mathrm{mol} 2$ & -87.9906 & -22.3072 & -63.0445 & 1 & 130.432 \\
\hline $9883304 . \mathrm{mol} 2$ & -88.9778 & -22.2999 & -66.1489 & 1 & 134.962 \\
\hline $9883304 . \mathrm{mol} 2$ & -84.9977 & -23.1765 & -60.3121 & 1 & 135.093 \\
\hline $9883304 . \mathrm{mol} 2$ & -82.0807 & -20.5831 & -71.7691 & 1 & 130.134 \\
\hline
\end{tabular}

Table 6: Experimental Data Snapshot

\begin{tabular}{|l|l|}
\hline Method: & X-RAY DIFFRACTION \\
Resolution: & $2.80 \AA$ \\
R-Value Free: & 0.230 \\
R-Value Work: & 0.213 \\
R-Value Observed: & 0.213 \\
\hline
\end{tabular}

Finish (estimated): 14:25:38. Remaining: 00:00:02

Working path: C:/Users/Bashah/Desktop/data/barkha mam gbu/ibri assignment ashish/lung cancer/dock result Current ligand (10/10 runs)

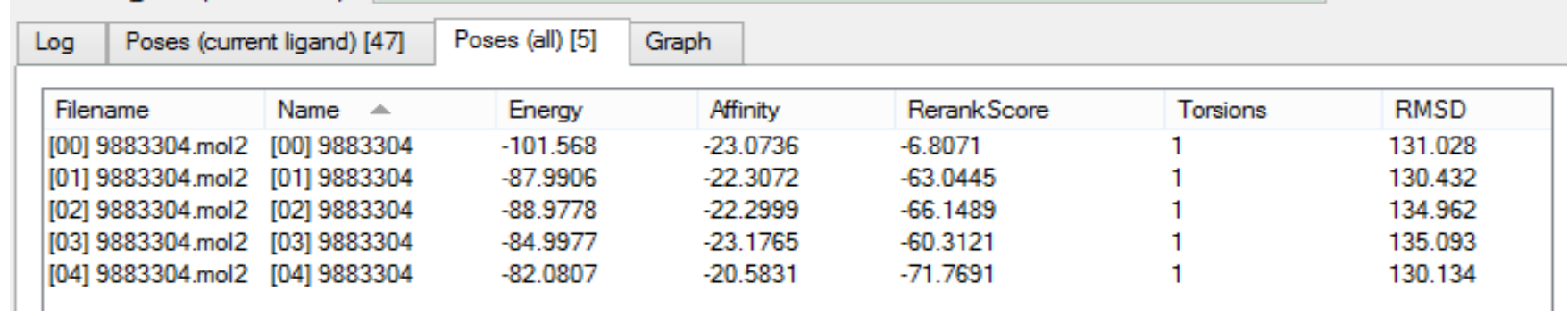

Figure 8: Experimental data Snapshot of lung cancer 
We found that Cell viability after treatment with the methanolic and aqueous extract of Laccifer lacca in the effect of L.L on Hela cell viability the aqueous extract has more effect with comparison in methanolic extract.



Figure 9: Cell viability after treatment with the methanolic and aqueous extract of Laccifer lacca. It is expressed in percentage in the ratio with the control cells.

We found that the cytokines levels were compared with the control and vinblastine that control group has more level of cytokines which is $\mathrm{mg} / \mathrm{ml}$.

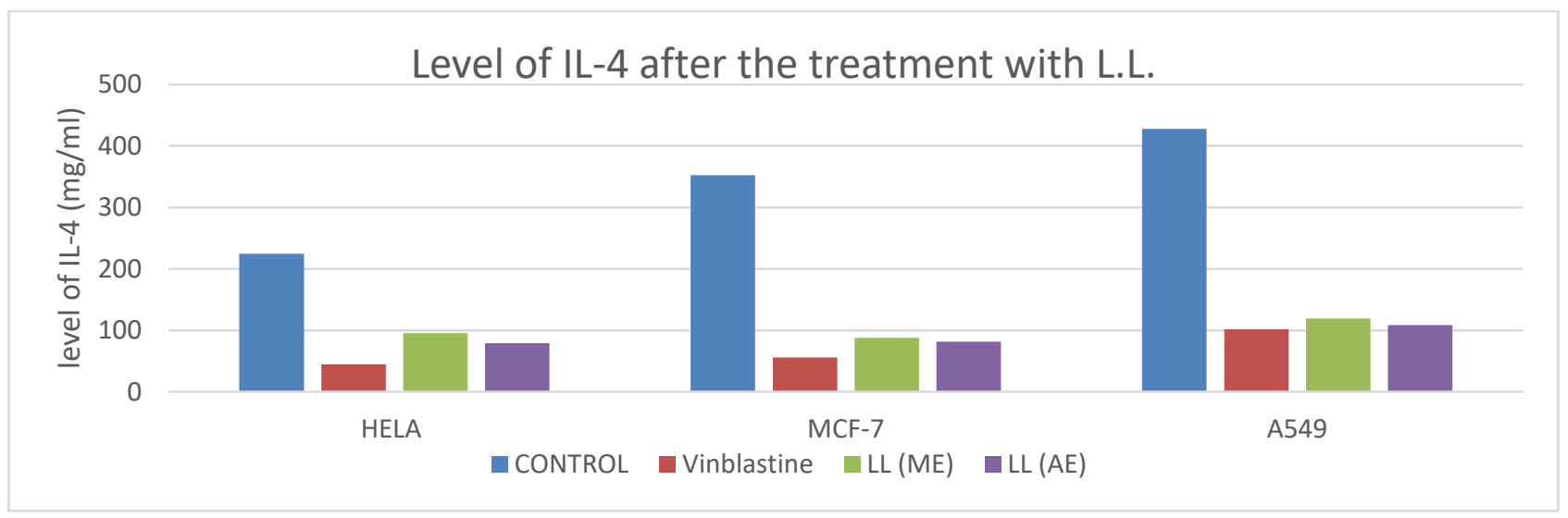

Figure 10: Cytokine measurement by kit based ELISA. The levels of cytokines are measured in $\mathrm{mg} / \mathrm{ml}$. The cytokines levels were compared with the control and standard vinblastine.

We found that the level of ROS in vinblastine group is more than methanolic extract and aqueous extract group of Laccifer lacca.

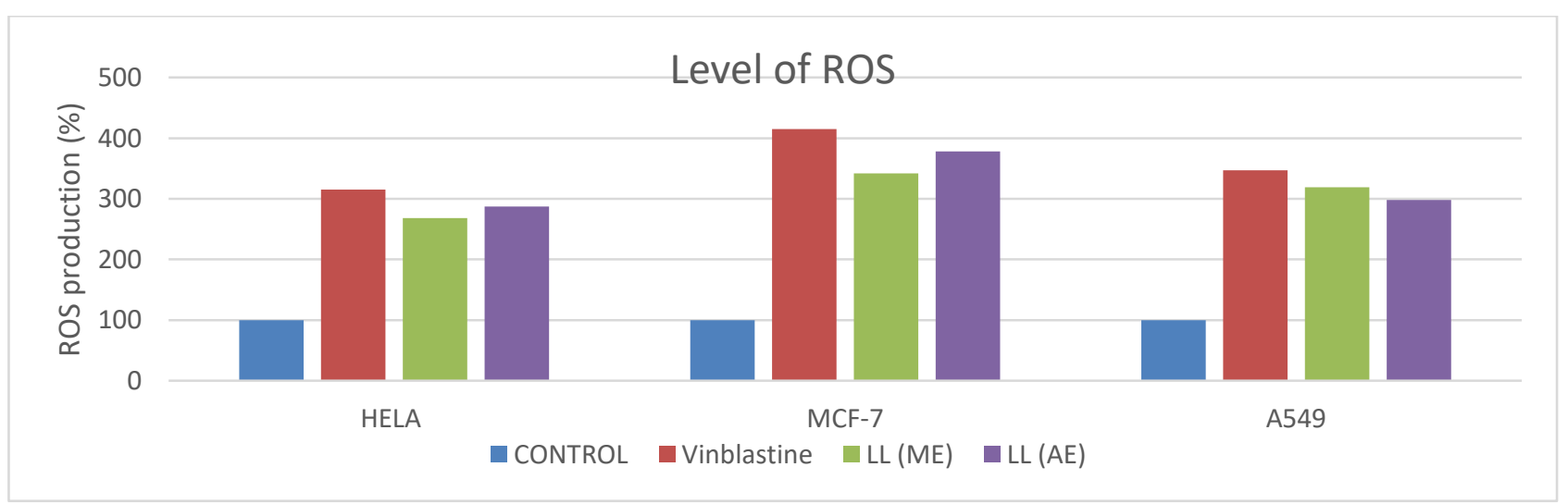

Figure 11: Measurement of reactive oxygen species production in the cells after the treatment with the standard drug and test extracts for 24 hours. The production is expressed as \%.

\section{DISCUSSION}

We were determined to analyse the therapeutic potential of the lac as anticancer agent and for that we prepared two preparation, one being aqueous and other is methanol extract. The treatment of cancer cells with lac resulted in the inhibition of cell proliferation in MTT assay. Methanolic extract is more efficient in the inhibition of cell proliferation when compared to the aqueous extract. It has been stressed enough that balance between pro- and anti- inflammation is very crucial for the body's health as well to fight off risks like cancer. The heightened pro-inflammatory milieu in our body may weaken the immune response and thus resulting in an increased risk of cancer. However, not all inflammation is bad for our body, inflammation is also important to stimulate the body's immune response and signal it to fight against the cancer cells. Therefore, now it has been considered that anti-inflammatory properties are an addition to the anti-cancer properties of the drug. Plants foods are known to have anti-inflammatory constituents as well as anti-oxidants. We analysed our drug lac for its antiinflammatory properties against the cancer cell lines. We 
measured the levels of anti-inflammatory markers IL-4 \& IL10 in the cell supernatant after treating them with extracts of lac and standard drug vinblastine.

\section{CONCLUSION}

In conclusion, we found out that laccifer lacca extract enhances the production of anti-inflammatory markers and the increase is significant when compared to the standard vinblastine. It has been demonstrated by Lala and colleagues that a short lived molecule nitric oxide can result in the progression of human tumours. Therefore, the prominent antioxidant activity of phytochemical that can act as inhibitors of NO production can act as anticancer therapeutics. We measured the levels of nitric oxide (NO) in the treated cells and it was found that the levels of NO were decreased after treatment. Both methanolic and aqueous extract shows significant anti-cancer effect on the hela, MCF7 \& A549 cells suggesting them as potential anticancer therapeutics for future.

\section{ACKNOWLEDGEMENT}

First and foremost, I express my sincere gratitude to almighty due to which I have been made possible for me to reach this so far. It is my profound privilege to have carried out this research work under men of such thinking, Respected Mr. Balwan Singh, Associate Professor \& HOD and Mr. Neeraj Kumar, Assistant Professor at HIMT College of Pharmacy, Greater Noida. Their intellect and words of wisdom have been a constant source of enlightenment and have dwelled like snow on my mind. With a deep sense of gratitude, I acknowledge the continuous help, encouragement and constant support of the Principal and non-teaching staff of the college. I am also very pleased to acknowledge the continuous help and co-operation from IBRI, Noida Department of Molecular Docking, Noida.

\section{CONFLICT OF INTEREST:}

Authors report no conflict of interest in publishing this research work.

\section{REFERENCES}

1. Sharma S K, Shukla S K, Vaid D N. Shellac-structure, characteristics \& modification. Defence Science Journal, 1983; 33(3):261-271.

2. Prasad N, Agarwal S C. A convenient method for isolation of jalaric and aleuritic acids from shellac. Res. Ind., 1990; 35(3):164-166.

3. Ha C Y, Wang D X. Studies on the composition of domestic lac resin. Chem. Ind. For. Prod., 1992; 12(1):43-48.

4. Altstadt T.G., Fairchild C.R., Golik J., Johnston K.A., Kadow J.F., Lee F.Y., Long B.H., Rose W.C., Vyas D.M., Wong H., Wu M.J. and Wittman M.D. Synthesis and antitumor activity of novel C-7 paclitaxel ethers: discovery of BMS-184476. Journal of Medicinal Chemistry, 2001; 44(26):4577-4583.

5. Balunas M.J. and Kinghorn A.D. Drug discovery from medicinal plants. Life Sciences, 2005; 78(5):431-441.

6. Choy H., Safran H., Akerley W., Graziano S.L., Bogart, J.A. and Cole, B.F. Phase II trial of weekly paclitaxel and concurrent radiation therapy for locally advanced non-small-cell lung cancer. Clinical Cancer Research, 1998; 4(8):1931-1936.

7. Christian M.C., Pluda J.M., Ho T.C., Arbuck S.G., Murgo A.J. and Sausville, E.A. Promising new agents under development by division of cancer treatment, diagnosis, and centers of the National Cancer Institute. Seminars in Oncology, 1997; 24(2):219-40

8. Cichewitz R.H. and Kouzi S.A. Chemistry, biological activity, and chemotherapeutic potential of betulinic acid for the prevention and treatment of cancer and HIV infection. Medicinal Research Reviews, 2004; 24(1):90-114.

9. Cisternino S., Bourasset F., Archimbaud Y., Semiond D., Sanderink G. and Scherrmann J.M. Nonlinear accumulation in the brain of the new taxoid TXD258 following saturation of Pglycoprotein at the blood-brain barrier in mice and rats. British Journal of Pharmacology, 2003; 138(7):1367-1375.

10. Cragg G.M. and Newman D.J. Plants as source of anticancer agents. Journal of Ethno pharmacology, 2005; 100(1-2):72-79.

11. Jimtaisong A, Janthadee $R$ \& Nakrit $T$, In vitro antioxidant activities of laccaic acids and its aluminum lake, Food Sci. Biotechnol., 2013; 22(4):1055-1061.

12. Cragg G.M., Newman D.J. and Snader K.M. Natural products in drug discovery and development. Journal of Natural Products, 1997; 60(1):52-60.

13. Dhanamani M., Lakshmi Devi S. and Kannan S. Ethnomedicinal plants for cancer therapy- A review. Hygeia-Journal for Drugs and Medicines, 2011; 3(1):1-10.

14. Doorbar J. Molecular biology of human papilloma virus infection and cervical cancer. Clinical Science, 2006; 110(5):525-541.

15. Hartwell J.L. Plants used against cancer: a survey. 1971; 34(2):204-55.

16. Hwang B.Y., Su B.N., Chai H., Mi Q., Kardono L.B., Afriastini J.J., Riswan S., Santarsiero, B.D., Mesecar, A.D., Wild, R., Fairchild, C.R., Vite, G.D., Rose, W.C., Farnsworth, N.R., Cordell, G.A. Pezzuto, J.M., Swanson, S.M. and Kinghorn, A.D. Silvestrol and episilvestrol, potential anticancer rocaglate derivatives from Aglaila silvestris. Journal of Organic Chemistry, 2004; 69(10):3350-3358.

17. Itokawa H., Wang X. and Lee K.H. Homoharringtonine and related compounds. In: Cragg, G.M., Kingston, D.G.I. and Newman, D. (eds). Anticancer agents from natural products, 2005; 47-70

18. Kantarjian H.M., O’Brien S., Anderlini P. and Talpaz M. Treatment of chronic myelogenous leukemia: current status and investigational options. Blood, 1996; 87(8):3069-3081.

19. Kappor L.D. Handbook of ayurvedic medicinal plants, CRC press, Boca Raton, Florida. 1990; 416-17.

20. Kelland L.R. Flavopiridol the first cyclic-dependent kinase inhibitor to enter the clinic: current status. Expert Opinion on Investigational Drugs, 2000; 9(12):2903-2911.

21. Mastalerz H., Cook D., Fairchild C.R., Hansel S., Johnson W., Kadow J.F., Long B.H., Rose W.C., Tarrant J., Wu, M.J., Xue, M.Q., Zhang, G., Zoeckler, M. and Vyas, D.M. The discovery of BMS275183: an orally efficacious novel taxane. Bioorganic Medicinal Chemistry, 2003; 11(20):4315-4323.

22. Nicoletti M.I., Colombo T., Rossi C., Monardo C., Stura S., M. Zucchetti A. Riva P. Morazzoni M. B. Donati E. Bombardelli M., D'Incalci M. and Giavazzi, R. IDN5109, A taxane with oral bioavailability and potent antitumor activity. Cancer Research, 2000; 60(4):842-846.

23. Parkin D.M. The global health burden of infection-associated cancers in the year 2002. International Journal of Cancer, 2006; 118(12):3030-3044.

24. Parkin D.M., Bray F., Ferlay J., Pisani P. Global cancer statistics, CA: A Cancer Journal for Clinicians, 2005; 55(1):74-108.

25. Patwardhan, B., A.D.B. Vaidya, A.D.B. and Chorghade, M. Ayurveda and natural products drug discovery. Current Science, 2004; 86(6):789-799.

26. Polizzi D., Pratesi G., Monestiroli S., Tortoreto M., Zunino F., Bombardelli E., Riva A., Morazzoni P., Colombo T., D’Incalci T. and Zucchetti M. Oral efficacy and bioavailability of a novel taxane. Clinical Cancer Research, 2000; 6(5):2070-2074.

27. Powell, R.G., Weisleder, D., Smith, C.R. and Rohwedder, W.K. Structures of harringtonine, isoharringtonine, and homoharringtonine. Tetrahedron Letters, 1970; 11(11):815-818.

28. Premalatha B. and Rajgopal G. Cancerian ayurvedic perspective. Pharmacological Research, 2005; 51(1):19-30.

29. Rao G.V., Kumar S., Islam M. and Mansour S.E. Folk medicines for anticancer therapy- a current status. Cancer Therapy, 1999; 6(10):913-922.

30. Geraghty R J, Capes-Davis A, Davis J M. Guidelines for the use of cell lines in biomedical research. Br J. Cancer, 2014; 111(6):1021-46 